\title{
Catalytic Ozonation of Phenolic Wastewater: Identification and Toxicity of Intermediates
}

\author{
Mahdi Farzadkia, ${ }^{1}$ Yousef Dadban Shahamat, ${ }^{2}$ Simin Nasseri, ${ }^{3}$ Amir Hossein Mahvi, \\ Mitra Gholami, ${ }^{1}$ and Ali Shahryari ${ }^{2,4}$ \\ ${ }^{1}$ Department of Environmental Health Engineering, School of Public Health, Iran University of Medical Sciences, Tehran, Iran \\ ${ }^{2}$ Environmental Health Research Center, Golestan University of Medical Sciences, Gorgan 4918936316, Iran \\ ${ }^{3}$ Department of Environmental Health Engineering, School of Public Health, Tehran University of Medical Sciences, Tehran, Iran \\ ${ }^{4}$ Department of Environmental Health Engineering, Environment Research Center, School of Health, Isfahan University of \\ Medical Sciences, Isfahan, Iran
}

Correspondence should be addressed to Yousef Dadban Shahamat; ydadban@yahoo.com

Received 18 December 2013; Revised 5 March 2014; Accepted 11 March 2014; Published 6 May 2014

Academic Editor: Jong M. Park

Copyright (C) 2014 Mahdi Farzadkia et al. This is an open access article distributed under the Creative Commons Attribution License, which permits unrestricted use, distribution, and reproduction in any medium, provided the original work is properly cited.

\begin{abstract}
A new strategy in catalytic ozonation removal method for degradation and detoxification of phenol from industrial wastewater was investigated. Magnetic carbon nanocomposite, as a novel catalyst, was synthesized and then used in the catalytic ozonation process (COP) and the effects of operational conditions such as initial $\mathrm{pH}$, reaction time, and initial concentration of phenol on the degradation efficiency and the toxicity assay have been investigated. The results showed that the highest catalytic potential was achieved at optimal neutral $\mathrm{pH}$ and the removal efficiency of phenol and COD is $98.5 \%$ and $69.8 \%$, respectively. First-order modeling demonstrated that the reactions were dependent on the initial concentration of phenol, with kinetic constants varying from $0.038 \mathrm{~min}^{-1}\left([\mathrm{phenol}]_{o}=1500 \mathrm{mg} / \mathrm{L}\right)$ to $1.273 \mathrm{~min}^{-1}\left([\mathrm{phenol}]_{o}=50 \mathrm{mg} / \mathrm{L}\right)$. Bioassay analysis showed that phenol was highly toxic to Daphnia magna $\left(\mathrm{LC}_{50} 96 \mathrm{~h}=5.6 \mathrm{mg} / \mathrm{L}\right.$ ). Comparison of toxicity units (TU) of row wastewater $(36.01)$ and the treated effluent showed that TU value, after slightly increasing in the first steps of ozonation for construction of more toxic intermediates, severely reduced at the end of reaction (2.23). Thus, COP was able to effectively remove the toxicity of intermediates which were formed during the chemical oxidation of phenolic wastewaters.
\end{abstract}

\section{Introduction}

phenol is a hazardous contaminant and classified as a toxic and priority hazardous contaminant in the list of USEPA [1], which can be found in aqueous effluents from various industries such as the petrochemical plants, petroleum refineries, manufacturing of resins and plastics, steel production, coal conversion, surface runoff from coal mines, dyestuff, tanning, paint stripping operations, pulp and paper, pesticides, pharmaceuticals, medications, and food processing industries [2, 3]; Environmental Protection Agency has limited this contaminant concentration in surface waters to less than 1 ppb [4]. Due to its toxicity and hazardous character and an increasing social concern on environment, it is required to be removed prior to discharging to the environment. Therefore, because the traditional methods of treatment of phenolic wastewaters such as physical and biological processes are not sufficient and have their own limitations, there is a need to use effective strategies of treatment.

Many investigations are available regarding the use of advanced oxidation processes (AOPs) such as ultrasonic, photooxidation, photocatalytic oxidation plasma, Fenton, photo-Fenton, wet oxidation, and ozone/ultraviolet (UV) for the degradation and mineralization of various classes of biorecalcitrant organic compounds [5] that, based on economic consideration and their complexity, rarely selected as a possible process.

Ozonation is one of the oxidation processes widely used for industrial wastewater pretreatment in which ozone molecules (as a strong oxidant) break down recalcitrant and 
toxic organic compounds into smaller molecules. However, ozonation has some limitations such as the following: (1) high energy consumption for ozone generation which could be costly; (2) in some cases ozonation is selective; (3) incomplete oxidation and low efficiency due to low reaction kinetics and limited mass transfer $[4,6]$; and incomplete mineralization of recalcitrant organics [7].

In recent years, significant attention has been paid on the catalytic ozonation process (COP). Indeed, COP is a new AOP in which a catalyst is applied to increase the soluble ozone decomposition, as result, producing highly reactive hydroxyl radicals [8]. These nonselective radicals are capable of oxidizing the refractory and toxic organic compounds into final inorganic and less toxic products [9].

Many studies have reported that the treatment process can be improved by combining ozonation with other agents such as $\mathrm{UV}, \mathrm{H}_{2} \mathrm{O}_{2}$, and homogeneous catalysts, for instance, $\mathrm{Mn}^{+2}, \mathrm{Fe}^{+3}, \mathrm{Fe}^{+2}, \mathrm{Ag}^{+}, \mathrm{Zn}^{+2}$, and $\mathrm{Co}^{+2}[10,11]$.

But, due to high consumption of the catalyst and complexity of these technologies, it is rarely selected as a promising method.

Recently, heterogeneous catalytic ozonation processes, as a powerful treatment method, have been investigated to increase the efficiency of ozonation process. In this process, a synthesized catalyst is applied to increase the ozone decomposition and thereby form highly reactive free radicals. Many catalysts including metals and metal oxides such as $\mathrm{CO}_{3} \mathrm{O}_{4} / \mathrm{CeO}_{2}, \mathrm{TiO}_{2}, \mathrm{Pt} /$ carbon nanotube (CNT), $\mathrm{Ru} / \mathrm{Al}_{2} \mathrm{O}_{3}, \mathrm{Mn} / \mathrm{TiO}_{2}, \mathrm{Au} / \mathrm{AC}, \mathrm{Mn} / \mathrm{Co}, \mathrm{Fe}_{3} \mathrm{O}_{4} / \mathrm{CoO}, \mathrm{ZnO}$, $\mathrm{Fe}_{2} \mathrm{O}_{3}, \mathrm{Fe}_{2} \mathrm{O}_{3} / \mathrm{CeO}_{2}, \mathrm{CNT}, \mathrm{Ru} / \mathrm{CeO}_{2}, \mathrm{Cu} / \mathrm{ZrO}, \mathrm{CuFe}_{2} \mathrm{O}_{4}$, and activated carbon (AC) are widely used for enhancing the activation of the ozonation process [12-15].

The coupling of ozone and activated carbon was proven to be an effective method to degrade organic contaminants [9, 16]. In this method, carbon can act as an adsorbent, a reactive support, and free-radical initiator [6, 14], but irreversibility and high consumption still remain the main disadvantages of this catalyst.

In this study, carbon nanocomposite was applied as a catalyst for heterogeneous ozonation. This catalyst has superparamagnetic properties that could be recovered from effluent by magnetic field and reused for several times.

Hence, this research is focusing on the degradation and detoxification of phenol and intermediates by COP, and the influences of some operational conditions such as initial $\mathrm{pH}$ of the solution, reaction time, and initial concentration of phenol on the degradation and the COD removal efficiencies were evaluated.

For control and optimization of this treatment method, it is necessary to understand the role of this catalyst and the nature of the reactions. Accordingly, in this research, the physical and chemical properties of the nanocomposite, such as specific surface area, $\mathrm{pHzpc}$, and its composition were determined and later discussed in detail.

Also, toxicity of phenol stream and identification of intermediates in the various reaction time of COP were carried out using Daphnia magna and GC/MS, respectively. In this study, the $\mathrm{LC}_{50}$, which is considered as the concentration of toxic compound which results on average in a $50 \%$ mortality of the test organisms at a specific exposure time, was investigated.

In order to determine changes in effluent acute toxicity during the $\mathrm{COP}$, toxicity values $\left(\mathrm{LC}_{50}\right)$ were converted to toxic unit values (TU) and then considered as an indication of the comparison.

\section{Materials and Methods}

2.1. Chemicals. Phenol (purity $\geq 99.5 \%$; CAS number 108 95-2) was purchased from Merck Co. (Germany). Then standard solutions were prepared with distilled and deionized water, protected from light, and stored at $4^{\circ} \mathrm{C}$. Except for HPLC-grade acetonitrile, all other chemical agents such as (KI), $\left(\mathrm{Na}_{2} \mathrm{~S}_{2} \mathrm{O}_{5}\right),\left(\mathrm{Na}_{2} \mathrm{SO}_{3}\right)$, sulfuric acid, nitric acid, sodium hydroxide, $\left(\mathrm{KCr}_{2} \mathrm{O}_{7}\right),\left(\mathrm{Ag}_{2} \mathrm{SO}_{4}\right),\left(\mathrm{HgSO}_{4}\right), \mathrm{NaH}_{2} \mathrm{PO}_{4}$, and $\mathrm{Fe}$ $\left(\mathrm{NO}_{3}\right)_{3} \cdot 9 \mathrm{H}_{2} \mathrm{O}$ were of analytical reagent grade. A commercial powder activated carbon (CAS number 1.02183.1000) supplied by Merck Co. was used in this study as a precursor of the catalyst.

2.2. Preparation and Characterization of the Catalyst. The nanocomposite catalyst was prepared from activated carbon (AC) via a modified impregnation method by using $\mathrm{Fe}_{3} \mathrm{O}_{4}$. Firstly, the AC was treated with nitric acid (37\%) and the resulting mixture was kept at $80^{\circ} \mathrm{C}$ and stirred for $3 \mathrm{~h}$ to make it hydrophilic. Then, it was washed with water, filtered, and dried at $105^{\circ} \mathrm{C}$ over night. $25 \mathrm{~g}$ of the modified AC was dispersed in $200 \mathrm{~mL}$ aqueous solution containing $100 \mathrm{~g} \mathrm{Fe}$ $\left(\mathrm{NO}_{3}\right)_{3} \cdot 9 \mathrm{H}_{2} \mathrm{O}$ as a $\mathrm{Fe}_{3} \mathrm{O}_{4}$ precursor by sonication using an ultrasonic bath. The resulting particles then filtrated and dried and the thermal treatment was performed at $700^{\circ} \mathrm{C}$ for $1 \mathrm{~h}$ in the presence of pure nitrogen flow for the formation of $\mathrm{Fe}_{3} \mathrm{O}_{4}$ magnetic nanoparticles.

The specific surface area of the prepared catalyst was determined using the BET equation and its mineralogical characterization was specified by X-ray diffraction (XRD) patterns carried out on an XRD diffractometer at room temperature. The distribution of elements on the catalyst was determined by dispersive X-ray spectroscopy (EDS) and its morphology was characterized by scanning electron microscopy (SEM) analysis. The $\mathrm{pH}$ of the zero point of charge ( $\mathrm{pHzpc}$ ) of the catalyst was measured by acid-base titration of catalyst suspension method, which is detailed by Altenor et al. [17].

2.3. Catalytic Ozonation Treatment. The ozone was generated from pure oxygen via corona discharge using an ozone generator (ARDA, Model COG-1A) with $5 \mathrm{~g} \mathrm{O}_{3} /$ h capacity. The ozone inlet flow rate was controlled via a gas rotameter (capacity, $3.5 \mathrm{~L} / \mathrm{min}$ ) at $0.5 \mathrm{~L} / \mathrm{min}$.

The ozone was regulated at a constant mass flow rate of $33 \mathrm{mg} /(\mathrm{L} \cdot \mathrm{min})$ throughout the experiments, measured by the standard potassium iodide (KI) absorption method [18] and finally destroyed in the off-gas stream of the reactor in a concentrated KI solution.

The samples containing phenol were prepared from the stock solution $(5000 \mathrm{mg} / \mathrm{L})$ and their residual concentrations 
TABLE 1: Experimental steps and conditions.

\begin{tabular}{|c|c|c|c|c|c|}
\hline \multirow{2}{*}{ Phase } & \multirow{2}{*}{ Experiment } & \multicolumn{4}{|c|}{ Conditions } \\
\hline & & $C_{\text {Phenol }}(\mathrm{mg} / \mathrm{L})$ & $C_{\text {Catalyst }}(\mathrm{g} / \mathrm{L})$ & $\mathrm{pH}$ & Time (min) \\
\hline 1 & Effect of $\mathrm{pH}$ & 100 & 0.5 & $4-10$ & 5 \\
\hline 2 & Effect of initial concentration of phenol & $50-1500$ & 2 & $8^{\mathrm{a}}$ & $0-60$ \\
\hline 3 & Phenol and COD removal at optimal condition & 500 & 2 & 8 & $0-60$ \\
\hline 4 & Toxicity of effluents & 200 & 2 & 8 & $0,10,30$ and 60 \\
\hline 5 & Identification of intermediates & 500 & 2 & 8 & 15 \\
\hline
\end{tabular}

${ }^{\mathrm{a}}$ Optimum $\mathrm{pH}$ in which the maximum phenol removal was obtained in COP.

in the samples were analyzed by HPLC (Cecil CE 4100) using a Hypersil C18 column $(250 \mathrm{~mm} \times 4.6 \mathrm{~mm}$ i.d, with $5 \mu \mathrm{m}$ particle size) with a UV detector (Cecil CE 4200) at $254 \mathrm{~nm}$. The mobile phase consisted of a mixture of $50 \mathrm{mM}$ buffer solution $\left(\mathrm{NaH}_{2} \mathrm{PO}_{4}\right)$ and acetonitrile $(50: 50, \mathrm{v}: \mathrm{v})$ at a flow rate of $1.0 \mathrm{~mL} \mathrm{~min}^{-1}$.

The experiments regarding the catalytic ozonation were carried out in a semibatch cylindrical stainless steel reactor with $1 \mathrm{~L}$ total volume fitted with other elements including an ozone generator, a sintered diffuser to distribute the ozone stream into the solution, a cylinder of pure oxygen (99.9\%), an ozone off-gas trap system, and gas rotameter. For each catalytic ozonation test, the following procedure was made.

(1) A $1 \mathrm{~L}$ solution of phenol with a certain initial concentration was transferred into the reactor.

(2) The initial $\mathrm{pH}$ of the solution was adjusted at the desired value by the addition of either $\mathrm{NaOH}$ or $\mathrm{HCl}$ (1 M).

(3) The required amount of catalyst was added to the solution.

(4) The ozonation was started at a certain time (see Table 1).

At given time intervals, $2 \mathrm{~mL}$ of the sample was immediately introduced into $100 \mu \mathrm{L}$ of sulphite solution $(0.1 \mathrm{M})$ to remove the dissolved ozone. The magnet and filter $(0.22-$ $\mu \mathrm{m}$ ) were used to remove the catalyst and then $60 \mu \mathrm{L}$ of the recovered sample was injected to the HPLC for analysis of the residual phenol. The condition of experiments was optimized using one factor at a time method.

The extent of mineralization of the organic matter was measured by COD experiment via digestion of the treated sample in COP with $\mathrm{KCr}_{2} \mathrm{O}_{7}$ solution [18].

2.4. Kinetic Studies. The kinetic study in both COP and single ozonation process (SOP) was carried out with different concentrations of catalyst and phenol. The following firstorder kinetic expression was used to determine the phenol removal reaction rate, given by

$$
-\ln \left(\frac{C}{C_{0}}\right)=k t
$$

where $k$ is the first-order rate constant and $C$ and $C_{0}$ are the phenol concentrations at reaction time $t$ and initial phenol concentration, respectively.
2.5. Toxicity and Intermediates Identification of COP Effluent. Acute toxicity of phenol and its intermediate products after degradation by COP were investigated with infants of Daphnia magna as detailed in standard methods for the examination of water and wastewater [18].

Daphnia is a very sensitive organism to phenol [19]; therefore, toxicity tests were done using this animal.

Dilution water was taken from spring with the chemical properties of $\mathrm{pH}=7.9$, electrical conductivity $=987 \mu \mathrm{S} / \mathrm{cm}$, total hardness $=285 \mathrm{mg} / \mathrm{L}$ as $\mathrm{CaCO}_{3}$, total alkalinity $=$ $125 \mathrm{mg} / \mathrm{L}$ as $\mathrm{CaCO}_{3}$, chloride $=38 \mathrm{mg} / \mathrm{L}$, and nitrate $=$ $5.7 \mathrm{mg} / \mathrm{L}$. D. magna was maintained in a $20 \mathrm{~L}$ glass vessel containing dilution water in temperature of $23 \pm 2^{\circ} \mathrm{C}$ and a 14/10 light-dark cycle. In each experiment, 10 infants $(<24 \mathrm{~h}$ old) were transferred to the test volume of $200 \mathrm{~mL}$ in a $500 \mathrm{~mL}$ glass beaker with a Pasteur pipette.

In order to determine the toxicity of phenol and its intermediates, the initial concentration of this contaminant was $200 \mathrm{mg} / \mathrm{L}$, which ozonated with the catalyst at the reaction times of $0,10,30$, and $60 \mathrm{~min}$, and the effluents were diluted to $100,75,50,25,12.5,5,2.5,1,0.5$, and $0.25 \%$ with dilution water.

After the exposure times (24, 48, 72, and 96 hours), the number of immobilized and dead infants was recorded and $\mathrm{LC}_{50}$ values were calculated by usage of PROBIT program in the SPSS (version 21) software and the toxic unit (TU) of each effluent was determined by [20]

$$
\mathrm{TU}=\frac{100 \%}{\mathrm{LC}_{50}} .
$$

The intermediates formed during the degradation were monitored using a gas chromatograph-mass spectrometer (GC-MS) supplied by Agilent, USA, and a temperature program was as follows: the temperature of the column was initially set at $50^{\circ} \mathrm{C}$ for $2 \mathrm{~min}$, then increased by $10^{\circ} \mathrm{C}$ per min to $280^{\circ} \mathrm{C}$, and maintained at this isothermal temperature for the final $5 \mathrm{~min}$. Injector temperatures were set at 250 . Helium was used as a carrier gas at a flow rate of $1.0 \mathrm{~mL} / \mathrm{min}$ and the injections were made in the split mode with a split ratio of $1: 2$.

\section{Results and Discussion}

3.1. Characterization of Catalyst Particles. The modification by $\mathrm{HNO}_{3}$ can cause enhancement of surface area and pore volume of activated carbon. The surface area and the total 
pore volume (at $P / P_{o}=0.992$ ) of the catalyst were $814 \mathrm{~m}^{2} / \mathrm{g}$ and $0.26 \mathrm{~cm}^{3} / \mathrm{g}$, respectively. The surface area of magnetic catalyst was reduced from $907 \mathrm{~m}^{2} / \mathrm{g}$ to $814 \mathrm{~m}^{2} / \mathrm{g}$ (10\% reduction), attributing to the formation of nanoparticles of $\mathrm{Fe}_{3} \mathrm{O}_{4}$ inside the pores. Nanoparticles of $\mathrm{Fe}_{3} \mathrm{O}_{4}$ bonded on the surface of activated carbon by hydroxyl groups $[21,22]$. The functional groups of catalyst surface can be modified by ozone [23], by increasing the specific surface area of the pores, and by significant decreasing of the total volume of the catalyst [24]. However, once the activated carbon was ozonated, its specific surface area was slightly decreased, and the total volume of the pores remained unchanged [25]. Therefore, the influence of ozonation on the structure of the carbonbased catalyst is dependent on its origin and nature. X-ray diffraction (XRD) patterns of carbon nanocomposite were assigned to the synthesized carbon nanocomposites at $2 \theta=$ $24^{\circ}$ indicating that the AC structure was not destroyed after the calcination of the catalyst, and magnetic nanoparticles in the composite were actually pure $\mathrm{Fe}_{3} \mathrm{O}_{4}$. The result regarding the EDS analysis, shown in Table 2, reveals that around $90 \%$ of the synthesized catalyst contains pure carbon and 5\% of the total weight consists of iron and oxygen. The SEM results represent the nanoparticles of $\mathrm{Fe}_{3} \mathrm{O}_{4}$ with the particle sizes of $25-30 \mathrm{~nm}$. The result of catalyst characterization is summarized in Table 2.

\subsection{Parameters Affecting Ozonation}

3.2.1. Effect of pHzpc of the Catalyst and Initial PH of the Solution. The catalyst surface will be charged negatively when $\mathrm{pH}>\mathrm{pHzpc}$, positively when $\mathrm{pH}<\mathrm{pHzpc}$, and neutrally when $\mathrm{pH} \approx \mathrm{pHzpc}$. The $\mathrm{pH}$ of the solution can greatly affect the structural properties of the pollutant. Changes in the $\mathrm{pH}$ can alter the ions in solution, the ionic state of the phenol, and the surface properties of the catalyst.

The pHzpc of catalyst was measured 7.7, falling in the range of 6.08-7.7, reported by various researchers for similar catalysts $[9,26,27]$. It is demonstrated that the catalyst surface has slightly basic properties allowing the catalyst to induce ozone decomposition followed by the generation of reactive radical species [16].

Studies have shown that contribution of ozone molecules and modified activated carbon can cause to production of phenolic and hydroxyl groups. as the major functional groups on the surface of the catalyst, contributing acidic properties and low value of $\mathrm{pHzpc}$ [28].

These functional basic groups located on the surface of the catalyst are thought to be responsible for ozone decomposition, resulting in the generation of reactive radical species [16].

As observed in Figure 1, the rate of phenol degradation in SOP increased from $48 \%$ at $\mathrm{pH}$ of 4 (almost linearly) to $73 \%$ at the $\mathrm{pH}$ of 10 during a $5 \mathrm{~min}$ reaction time. This increase can be attributed to the effect of $\mathrm{pH}$ value on the ozone transfer rate from the gas flow to the liquid phase [16] and increase the concentration of $\mathrm{OH}$ anions (decomposition of ozone to reactive oxidizing radical species with the much higher oxidation potential than ozone molecules in the solution) [29].
TABLE 2: Specifications of nano- $\mathrm{Fe}_{3} \mathrm{O}_{4}$ coated on activated carbon.

\begin{tabular}{lcc}
\hline & PAC & $\mathrm{Fe}_{3} \mathrm{O}_{4} / \mathrm{AC}$ \\
\hline Parameters & & \\
Specific surface area $\left(\mathrm{m}^{2} / \mathrm{g}\right)$ & 907 & 814 \\
Pore volume $\left(\mathrm{cm}^{3} / \mathrm{g}\right)$ & 0.42 & 0.26 \\
$\mathrm{pHzpc}$ & 8.9 & 7.7 \\
Average particle size as $\mathrm{Fe}_{3} \mathrm{O}_{4}$ & - & $25-30$ \\
Elements & & \\
$\mathrm{Fe}(\%)$ & - & 5.04 \\
$\mathrm{O}(\%)$ & - & 5.76 \\
Assay (\%) as carbon & 99.99 & 89.20 \\
\hline
\end{tabular}

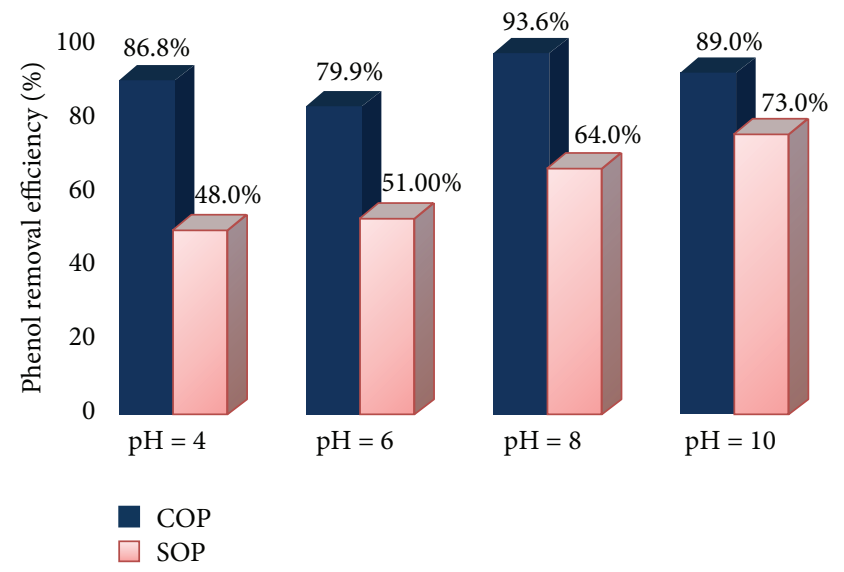

FIGURE 1: Effect of initial $\mathrm{pH}$ on removal efficiency of phenol. $[\mathrm{Phenol}]_{o}: 100 \mathrm{mg} / \mathrm{L}$; catalyst concentration of $0.5 \mathrm{~g} / \mathrm{L}$; reaction time: $5 \mathrm{~min}$.

In COP, due to the properties of the catalyst surface, the maximum degradation (93\%) was obtained at $\mathrm{pH}$ of 8 and above this $\mathrm{pH}(\mathrm{pH}=10)$, as other studies were reported, the degradation was decreased (89\%) $[6,30]$. As shown, at higher $\mathrm{pH}$, a negative effect on phenol degradation was observed, and the degradation rate of phenol was decreased under strong alkaline conditions (Figure 1). This result could be interpreted by considering both the property of phenol $(\mathrm{pKa}=9.9)$ and the surface nature of the catalyst, with respect to the $\mathrm{pH}$ of the solution and catalyst $\mathrm{pHzpc}$.

Since the pHzpc of catalyst is 7.7 , a negative charge is developed on its surface at this $\mathrm{pH}(>8)$. Phenol $(\mathrm{pKa}=9.9)$, on the other hand, is mostly dissociated to its ionic form (the phenolate anion) at this basic $\mathrm{pH}$ value [31]. The effect of $\mathrm{pH}$ value on the adsorption of phenol can be explained by the electrostatic interaction between the surface of the catalyst and the target material.

We found out, as expected, that the optimal $\mathrm{pH}$ was in $\mathrm{pK}_{\mathrm{ZPC}}^{\text {Catalyst }}<\mathrm{pH}<\mathrm{pH}_{\mathrm{a}}^{\mathrm{Phenol}}$ range. At this $\mathrm{pH}$, the negatively charged catalyst and positively charged phenol molecules should readily attract each other.

The affinity of catalyst toward phenolate through adsorption under strong alkaline condition is limited, leading to the reduction of phenol degradation rate [16]. Hence, under neutral and weak alkaline conditions ( $\mathrm{pH} 7-8)$, negative 


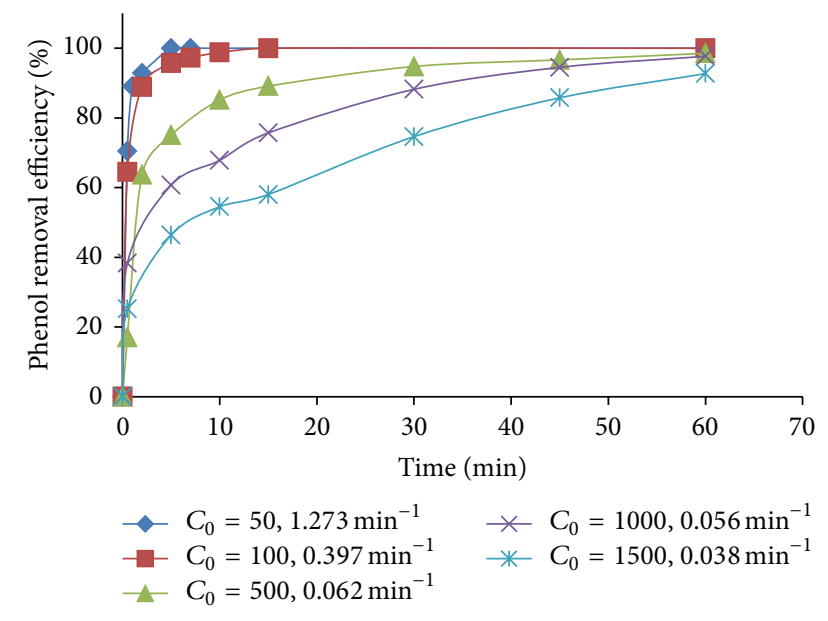

FIGURE 2: Effect of initial concentration of phenol on degradation efficiency in COP. Catalyst concentration of $2 \mathrm{~g} / \mathrm{L}$; initial $\mathrm{pH}$ of $8: 0$.

charge is the predominant surface charge for the catalyst and the positive charges are the primary species of the phenol contaminant. Therefore, both of them are easily attracted toward each other through hydrogen bonding and, consequently, the amount of phenol adsorption and its decomposition rate rise [30].

As Zhao et al. [32] pointed out, an increase was observed in the degradation rate of nitrobenzene in COP using a $\mathrm{Mn}$ catalyst with an increase in the $\mathrm{pH}$ of solution from 3 to 11 .

In further developments, some researchers have found out that a decline in the mineralization of phenolic compounds, was a function of $\mathrm{pH}$ of the solution from 3 to 10 [33].

It is also reported that the optimum $\mathrm{pH}$ for decolorization and mineralization of azo dye in COP using $\mathrm{MgO}$ nanocatalyst was found to be at alkaline $\mathrm{pH}$ over 8 [34].

It can be deduced that the process in which the $\mathrm{pH}$ of solution affects the degradation of a contaminant in COP depends on the structure, the type of the reacting compound, and the properties of the catalyst. Hence, the optimum $\mathrm{pH}$ of the COP must be selected for each specific condition.

Nonetheless, the maximum degradation rate in the COP was obtained at $\mathrm{pH}$ of 8.0 and the phenol degradation rate was remarkably higher in the COP than that of the SOP regardless of $\mathrm{pH}$. It is reported that increasement in the reaction efficiency can be due to the fact that ozone reacts indirectly with organic molecules at alkaline $\mathrm{pHs}$ [35].

3.2.2. Effect of Initial Concentration of Phenol. As illustrated in phase 2 of Table 1 , it can clearly be seen that the degradation of phenol, as a function of contaminant concentration (Figure 2), shows a significant declining effect of initial concentration of phenol on the ozonation process and kinetic constant, particularly in the first minutes of the reaction time.

For example, at a given reaction time of $5 \mathrm{~min}$, the degradation of phenol increased from $46.3 \%$ in the initial phenol concentration of $1500 \mathrm{mg} / \mathrm{L}$ to $99.9 \%$ at the phenol concentration of $50 \mathrm{mg} / \mathrm{L}$, representing the strong effect of

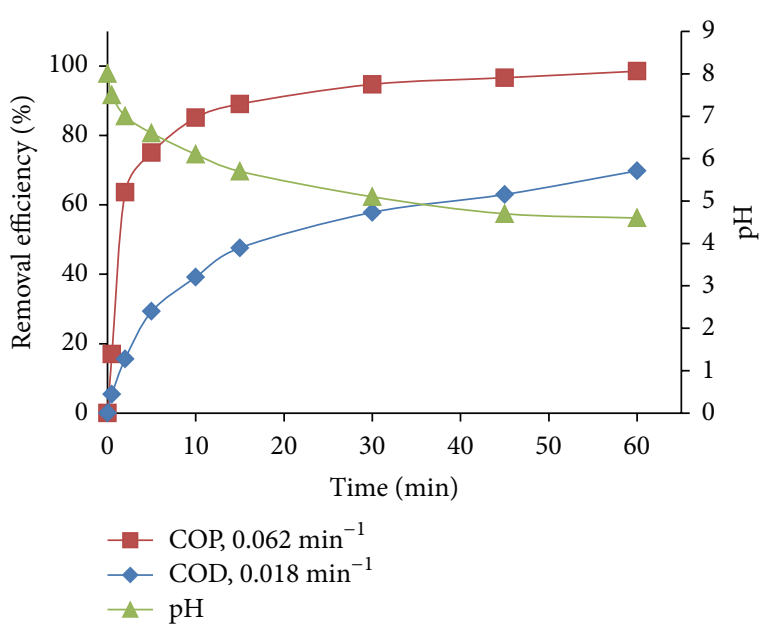

FIGURE 3: The degree of phenol degradation and COD removal in the COP, $[\text { phenol }]_{o}=500 \mathrm{mg} / \mathrm{L}$; catalyst concentration of $2 \mathrm{~g} / \mathrm{L}$; initial $\mathrm{pH}$ of $8: 0$.

contaminant concentration on ozonation. Also, the reaction rate constant increased from $0.038 \mathrm{~min}^{-1}$ in phenol concentration of $1500 \mathrm{mg} / \mathrm{L}$ to $1.273 \mathrm{~min}^{-1}$ with catalyst concentration of $2 \mathrm{~g} / \mathrm{L}$, indicating the 33 -fold increase in the reaction rate constant by decreasing of the initial contaminant concentration.

Based on the literature, the most likely mechanism of phenol degradation is as follows.

Ozone molecules are first adsorbed on the functional groups of the catalyst surface followed by decomposition by $\mathrm{AC}[6,12]$ and metal oxides including $\mathrm{Fe}_{3} \mathrm{O}_{4}[36]$. Afterwards, the generation of hydroxyl radicals and surface oxygenated radical species take place [37-39].

This result can be attributed to the expansion of surface area of the catalyst and the availability of more active sites for ozone decomposition leading to the enhancement of the following events: the available contact surface area for the reaction of phenol and ozone molecules [28], generation of reactive species of radicals [40-42], and the improvement of the phenol degradation efficiency.

3.3. Phenol and COD Removal at Optimal Condition. On completion of this investigation, the effect of the $\mathrm{COP}$ on the removal of COD from a phenolic sample was studied under the conditions defined in phase 3 of Table 1.

Since COD is a general measurement of the organics in the sample, its reduction denotes the amount of mineralization of the compounds [9]. As reported in the literature, the AOP causes a drastic reduction of COD of recalcitrant organics [7]. Our findings indicate that the COP is not exempt from this general principle. As shown in Figure 3, the phenol degradation efficiency was approximately $85 \%$ after $10 \mathrm{~min}$ of the reaction. But, approximately $39 \%$ of the COD of phenol were removed after the same reaction time, and it increases up to $70 \%$ after $60 \mathrm{~min}$, while in other similar studies, with other catalysts, COD removal efficiency from phenolic samples was lower than that of the above-mentioned values [43]. 
Although a further decrease (88\%) was reported by Moussavi et al. [9] in the COP of phenolic sample $\left(C_{0}=\right.$ $1200 \mathrm{mg} / \mathrm{L})$ at the end of reaction time $(60 \mathrm{~min})$, applying a 10-fold increase in the concentration of AC catalyst will overshadow its economic superiority.

The results show that the efficiency of COD removal and the reaction rate constants are lower than phenol degradation and its COD removal, particularly in early minutes of the reaction. This phenomenon can be illustrated in such a way that phenol molecules are converted to some intermediates prior to complete oxidation, especially at the initial steps of degradation.

The quick drop in $\mathrm{pH}$ value versus the reaction time confirms that acidic intermediates were generated during the oxidation of phenol (Figure 3 ). In addition, as the oxidation process is promoted by COP, the gap between COD and phenol removal percentage curves is narrowed. This could be due to the fact that intermediates are more efficiently mineralized in COP than their corresponding parent compounds. Overall, these results inferred that the COP with this catalyst could cause a high degree of degradation and mineralization of phenol compared to the other processes such as single ozonation [9, 44], Fenton and photo-Fenton [45], adsorption, $\mathrm{TiO}_{2}$-photocatalytic, wet air oxidation, and catalytic-based wet air oxidation [46].

Although the COP in the presence of nanocomposite catalyst was able to degrade almost completely all the phenol (98.5\%) and removed significant amounts of COD (70\%) after 60 min of reaction time, the rather long time of ozonation would impose high operational cost for the generation of required ozone on the treatment system.

As other studies reported [44], catalytic ozonation process improved the biodegradability at $\mathrm{BOD}_{5} / \mathrm{COD}$ ratio of phenolic compounds from only 0.3 to 0.52 and slightly reduced toxicity of the intermediate solution.

The results also showed that the COP not only efficiently degraded the phenol as a recalcitrant compound, but also prompted a high degree of COD removal and, consequently, the mineralization of its derivative intermediates.

3.4. Toxicity of COP Effluents. Results showed that Daphnia is very sensitive bioindicator to phenol [12], so that LC50 $96 \mathrm{~h}$ of row waste was $2.78 \% \mathrm{v} / \mathrm{v}$, which, with initial concentration of $200 \mathrm{mg} / \mathrm{L}$, was equal to $5.6 \mathrm{mg} / \mathrm{L}$. As can be seen in Figures 4 and 5 , acute toxicity of phenol and its intermediates were reduced significantly after being treated by COP. For instance, toxicity unit of phenol (according to $\mathrm{LC}_{50} 96 \mathrm{~h}$ ) by treatment with COP was reduced from 36 to 2.3 , which represents that the acute toxicity is reduced $\sim 16$ times at the end of reaction time (60 $\mathrm{min})$. As results showed, the toxicity of effluent after the first stages of COP slightly increased, which can be due to formation of more toxic intermediates such as catechol, hydroquinone, and benzoquinone [47].

Generally, the reduction of effluent toxicity was obtained by phenol and its intermediates to aliphatic and low chain carboxylic acids products.

Results of this research showed that the catalytic ozonation was able to eliminate effectively the toxicity of aqueous

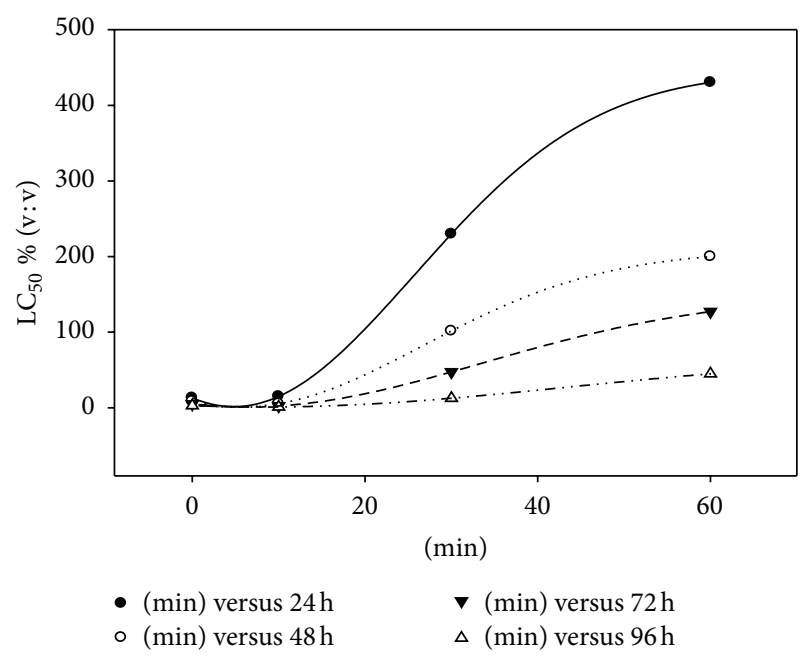

FIGURE 4: The change of $\mathrm{LC}_{50}$ of treated phenolic stream versus reaction time of COP, $[\text { phenol }]_{o}=200 \mathrm{mg} / \mathrm{L}$; catalyst concentration of $2 \mathrm{~g} / \mathrm{L}$; initial $\mathrm{pH}$ of $8: 0$.

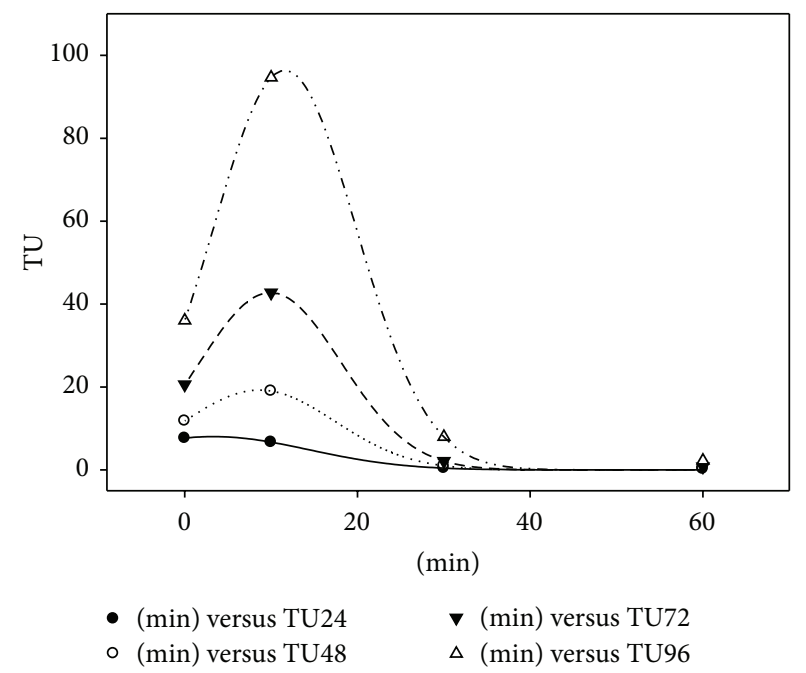

FIGURE 5: The change of toxic unit of treated phenolic stream versus reaction time of COP, $[\text { phenol }]_{o}=200 \mathrm{mg} / \mathrm{L}$; catalyst concentration of $2 \mathrm{~g} / \mathrm{L}$; initial $\mathrm{pH}$ of $8: 0$.

phenol and this technique can be used as a reliable method to detoxification of industrial phenolic effluents.

3.5. Identification of Intermediates. In this study, aromatic and aliphatic oxidation intermediates of phenol degradation were identified by GC/MS analysis as listed in Table 3 and shown in Figure 6.

Results showed that, after $1 \mathrm{~h}$ catalytic ozonation, phenol almost removed, while hydroquinone, benzoquinone, and catechol were present in small amount. At the end of reaction time carboxylic acids such as oxalic, fumaric, and acetic acids were formed as the main products of phenol degradation. Accordingly, at the end of reaction time, the $\mathrm{pH}$ value decreased from initial value of 8.0 to 4.5 (Figure 3). 
TABLe 3: Identified compounds by GC/MS.

\begin{tabular}{|c|c|c|c|}
\hline Compound & Formula & Structure & $\begin{array}{c}\text { Molar mass } \\
(\mathrm{g} / \mathrm{mol})\end{array}$ \\
\hline Formic acid & $\mathrm{CH}_{2} \mathrm{O}_{2}$ & & 46 \\
\hline Acetic acid & $\mathrm{C}_{2} \mathrm{H}_{4} \mathrm{O}_{2}$ & & 60 \\
\hline Oxalic acid & $\mathrm{C}_{2} \mathrm{H}_{2} \mathrm{O}_{4}$ & 0 & 90 \\
\hline Malonic acid & $\mathrm{C}_{3} \mathrm{H}_{4} \mathrm{O}_{4}$ & & 104 \\
\hline Benzaldehyde & $\mathrm{C}_{7} \mathrm{H}_{6} \mathrm{O}$ & & 106 \\
\hline p-Benzoquinone & $\mathrm{C}_{6} \mathrm{H}_{4} \mathrm{O}_{2}$ & & 108 \\
\hline $\begin{array}{l}\text { 1,2-Dihydroxybenzene } \\
\text { (catechol) }\end{array}$ & $\mathrm{C}_{6} \mathrm{H}_{6} \mathrm{O}_{2}$ & & 110 \\
\hline $\begin{array}{l}\text { 1,4-Dihydroxybenzene } \\
\text { (hydroquinone) }\end{array}$ & $\mathrm{C}_{6} \mathrm{H}_{6} \mathrm{O}_{2}$ & & 110 \\
\hline Fumaric acid & $\mathrm{C}_{4} \mathrm{H}_{4} \mathrm{O}_{4}$ & & 116 \\
\hline 4-Hydroxybenzoic acid & $\mathrm{C}_{7} \mathrm{H}_{6} \mathrm{O}_{3}$ & & 138 \\
\hline 2-Propylphenol & $\mathrm{C}_{9} \mathrm{H}_{12} \mathrm{O}_{2}$ & & 152 \\
\hline Phenoxy-phenol & $\mathrm{C}_{12} \mathrm{H}_{10} \mathrm{O}_{2}$ & & 186 \\
\hline
\end{tabular}




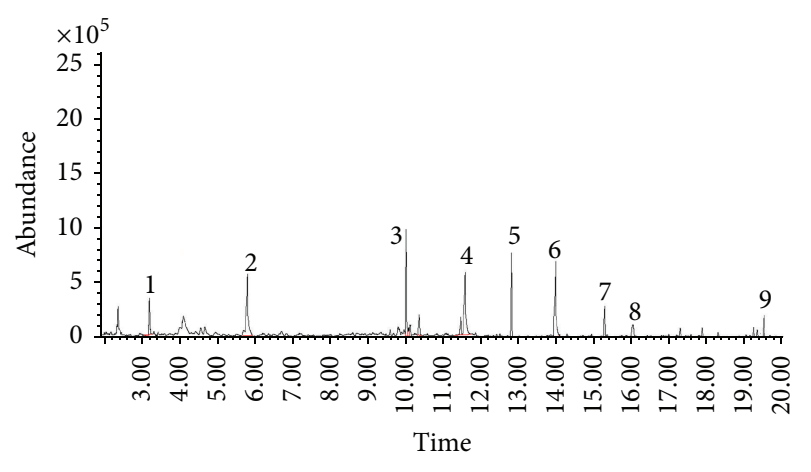

FIgURE 6: GC/MS chromatogram of phenol solution after being treated by COP for $15 \mathrm{~min}$ (peaks 1 and 2: lower carboxylic acids; peak 3: oxalic acid; peak 4: phenol; peak 5: 1,2-dihydroxy benzene; peak 6: 1,4-dihydroxy benzene; peak 7: 4-hydroxy-benzoic acid; peak 8: propylphenol; peak 9: phenoxyphenol), $[\mathrm{phenol}]_{o}=$ $500 \mathrm{mg} / \mathrm{L}$; initial $\mathrm{pH}$ of $8: 0$.

Also, the formation of coupling by-products such as phenoxyphenol with molecular weights higher than phenol was evidenced in this study, as it has been observed for other AOPs [48].

According to some findings $[9,43,49]$, major intermediates of phenol oxidation in AOPs can be categorized as readily biodegradable compounds (acetic, fumaric, propionic, formic, and succinic acids), nonbiodegradable compounds but without inhibitory or toxic effect over the biomass (maleic, oxalic, and malonic acids), toxic (p-benzoquinone and hydroquinone), and finally inhibitory compounds (catechol) for the biodegradation $[43,50]$.

\section{Conclusions}

In this study, the preparation of $\mathrm{AC} /$ nano- $\mathrm{Fe}_{3} \mathrm{O}_{4}$ composite used as a catalyst in the catalytic ozonation and detoxification of phenol has been investigated. This superparamagnetic nanocomposite exhibited a catalytic effect on the reactive radical generation.

The findings indicated that the removal efficiency and the constant rate of degradation increased with decreasing initial concentration of phenol and the optimum $\mathrm{pH}$ of solution was observed at $\mathrm{pH}$ of 8.0. At the initial concentration of $500 \mathrm{mg} / \mathrm{L}$ of phenol and the optimal conditions as well as $\mathrm{O}_{3}$ dosage of $33 \mathrm{mg} /(\mathrm{L} \cdot \mathrm{min}), 98.5 \%$ and $69.8 \%$ of phenol and COD were removed in the COP, respectively.

Despite more toxicity of effluent in the early stage of the catalytic ozonation, the toxicity of treated phenolic wastewater at the end of reaction was very low.

Accordingly, it is concluded that this nanocomposite is an efficient and active catalyst in the degradation and detoxification of phenol solution.

In spite of the high removal efficiency of phenol and low toxicity of effluent, the mineralization was incomplete.

Therefore, it is concluded that the combination of the biological process followed by COP is an effective and economic technique for the treatment of industrial wastewaters containing phenolic compounds.

\section{Conflict of Interests}

The authors declare that there is no conflict of interests regarding the publication of this paper.

\section{Acknowledgment}

The authors appreciate the Iran University of Medical Sciences for providing financial and instrumental support to conduct this work.

\section{References}

[1] A. Maleki, A. H. Mahvi, A. Mesdaghinia, and K. Naddafi, "Degradation and toxicity reduction of phenol by ultrasound waves," Bulletin of the Chemical Society of Ethiopia, vol. 21, no. 1, pp. 33-38, 2007.

[2] T. Saitoh, K. Asano, and M. Hiraide, "Removal of phenols in water using chitosan-conjugated thermo-responsive polymers," Journal of Hazardous Materials, vol. 185, no. 2-3, pp. 1369-1373, 2011.

[3] A. Maleki, A. H. Mahvi, and K. Naddafi, "Bioassay of phenol and its intermediate products using Daphnia magna," Water \& Wastewater Magazines \& Journals, vol. 5, no. 4, pp. 19-24, 2009.

[4] T. Luenloi, B. Chalermsinsuwan, T. Sreethawong, and N. Hinchiranan, "Photodegradation of phenol catalyzed by $\mathrm{TiO}_{2}$ coated on acrylic sheets: kinetics and factorial design analysis," Desalination, vol. 274, no. 1-3, pp. 192-199, 2011.

[5] M. Farzadkia, A. Esrafili, M. A. Baghapour, Y. D. Shahamat, and N. Okhovat, "Degradation of metronidazole in aqueous solution by nano-ZnO/UV photocatalytic process," Desalination and Water Treatment, 2013.

[6] Y.-F. Rao, H.-J. Luo, C.-H. Wei, and L.-F. Luo, "Catalytic ozonation of phenol and oxalic acid with copper-loaded activated carbon," Journal of Central South University of Technology, vol. 17, no. 2, pp. 300-306, 2010.

[7] P. Pocostales, P. Álvarez, and F. J. Beltrán, “Catalytic ozonation promoted by alumina-based catalysts for the removal of some pharmaceutical compounds from water," Chemical Engineering Journal, vol. 168, no. 3, pp. 1289-1295, 2011.

[8] H. Jung, H. Park, J. Kim et al., "Preparation of biotic and abiotic iron oxide nanoparticles (IOnPs) and their properties and applications in heterogeneous catalytic oxidation," Environmental Science and Technology, vol. 41, no. 13, pp. 4741-4747, 2007.

[9] G. Moussavi, A. Khavanin, and R. Alizadeh, "The investigation of catalytic ozonation and integrated catalytic ozonation/biological processes for the removal of phenol from saline wastewaters," Journal of Hazardous Materials, vol. 171, no. 1-3, pp. 175-181, 2009.

[10] C.-C. Chang, C.-Y. Chiu, C.-Y. Chang et al., "Pt-catalyzed ozonation of aqueous phenol solution using high-gravity rotating packed bed," Journal of Hazardous Materials, vol. 168, no. 2-3, pp. 649-655, 2009.

[11] Z. Wu, M. Franke, B. Ondruschka et al., "Enhanced effect of suction-cavitation on the ozonation of phenol," Journal of Hazardous Materials, vol. 190, no. 1-3, pp. 375-380, 2011.

[12] M. Sui, S. Xing, L. Sheng, S. Huang, and H. Guo, "Heterogeneous catalytic ozonation of ciprofloxacin in water with carbon nanotube supported manganese oxides as catalyst," Journal of Hazardous Materials, vol. 227-228, pp. 227-236, 2012. 
[13] Z.-Q. Liu, J. Ma, and Y.-H. Cui, "Carbon nanotube supported platinum catalysts for the ozonation of oxalic acid in aqueous solutions," Carbon, vol. 46, no. 6, pp. 890-897, 2008.

[14] G. Wu, T.-S. Jeong, C.-H. Won, and L. Cui, "Comparison of catalytic ozonation of phenol by activated carbon and manganese-supported activated carbon prepared from brewing yeast," Korean Journal of Chemical Engineering, vol. 27, no. 1, pp. 168-173, 2010.

[15] H. Zhao, Y. Dong, G. Wang et al., "Novel magnetically separable nanomaterials for heterogeneous catalytic ozonation of phenol pollutant: $\mathrm{NiFe}_{2} \mathrm{O}_{4}$ and their performances," Chemical Engineering Journal, vol. 219, pp. 295-302, 2013.

[16] G. Moussavi and R. Khosravi, "Preparation and characterization of a biochar from pistachio hull biomass and its catalytic potential for ozonation of water recalcitrant contaminants," Bioresource Technology, vol. 119, pp. 66-71, 2012.

[17] S. Altenor, B. Carene, E. Emmanuel, J. Lambert, J.-J. Ehrhardt, and S. Gaspard, "Adsorption studies of methylene blue and phenol onto vetiver roots activated carbon prepared by chemical activation," Journal of Hazardous Materials, vol. 165, no. 1-3, pp. 1029-1039, 2009.

[18] A. D. Eaton and M. A. H. Franson, Standard Methods for the Examination of Water \& Wastewater, American Public Health Association, 2005.

[19] A. Maleki, A. H. Mahvi, and F. V. R. Nabizadeh, "Ultrasonic degradation of phenol and determination of the oxidation by-products toxicity," Iranian Journal of Environmental Health Science \& Engineering, vol. 2, no. 3, 2005.

[20] R. Guerra, "Ecotoxicological and chemical evaluation of phenolic compounds in industrial effluents," Chemosphere, vol. 44, no. 8, pp. 1737-1747, 2001.

[21] A. A. Nunes, A. S. Franca, and L. S. Oliveira, "Activated carbons from waste biomass: an alternative use for biodiesel production solid residues," Bioresource Technology, vol. 100, no. 5, pp. 17861792, 2009.

[22] U. K. Garg, M. P. Kaur, V. K. Garg, and D. Sud, "Removal of hexavalent chromium from aqueous solution by agricultural waste biomass," Journal of Hazardous Materials, vol. 140, no. 1-2, pp. 60-68, 2007.

[23] H.-L. Chiang, P. C. Chiang, and C. P. Huang, "Ozonation of activated carbon and its effects on the adsorption of VOCs exemplified by methylethylketone and benzene," Chemosphere, vol. 47, no. 3, pp. 267-275, 2002.

[24] X. Qu, J. Zheng, and Y. Zhang, "Catalytic ozonation of phenolic wastewater with activated carbon fiber in a fluid bed reactor," Journal of Colloid and Interface Science, vol. 309, no. 2, pp. 429434, 2007.

[25] M. Sánchez-Polo, U. von Gunten, and J. Rivera-Utrilla, "Efficiency of activated carbon to transform ozone into $\cdot \mathrm{OH}$ radicals: influence of operational parameters," Water Research, vol. 39, no. 14, pp. 3189-3198, 2005.

[26] M. Danish, R. Hashim, M. N. M. Ibrahim, M. Rafatullah, T. Ahmad, and O. Sulaiman, "Characterization of Acacia mangium wood based activated carbons prepared in the presence of basic activating agents," BioResources, vol. 6, no. 3, pp. 3019-3033, 2011.

[27] G. Park, J. Lee, S. Ryu, and J. Kim, "Effect of two-step surface modification of activated carbon on the adsorption characteristics of metal ions in wastewater I. Equilibrium and batch adsorptions," Carbon Science, vol. 3, no. 4, pp. 219-225, 2002.

[28] A. Bhatnagar, W. Hogland, M. Marques, and M. Sillanpää, "An overview of the modification methods of activated carbon for its water treatment applications," Chemical Engineering Journal, vol. 219, pp. 499-511, 2013.

[29] H. Valdés, V. J. Farfán, J. A. Manoli, and C. A. Zaror, “Catalytic ozone aqueous decomposition promoted by natural zeolite and volcanic sand," Journal of Hazardous Materials, vol. 165, no. 1-3, pp. 915-922, 2009.

[30] F. J. Beltrán, F. J. Rivas, and R. Montero-de-Espinosa, "Mineralization improvement of phenol aqueous solutions through heterogeneous catalytic ozonation," Journal of Chemical Technology and Biotechnology, vol. 78, no. 12, pp. 1225-1233, 2003.

[31] K. László and A. Szücs, "Surface characterization of polyethyleneterephthalate (PET) based activated carbon and the effect of $\mathrm{pH}$ on its adsorption capacity from aqueous phenol and 2,3,4trichlorophenol solutions," Carbon, vol. 39, no. 13, pp. 19451953, 2001.

[32] L. Zhao, J. Ma, Z.-Z. Sun, and X.-D. Zhai, "Catalytic ozonation for the degradation of nitrobenzene in aqueous solution by ceramic honeycomb-supported manganese," Applied Catalysis B: Environmental, vol. 83, no. 3-4, pp. 256-264, 2008.

[33] R. C. Martins and R. M. Quinta-Ferreira, "Catalytic ozonation of phenolic acids over a Mn-Ce-O catalyst," Applied Catalysis B: Environmental, vol. 90, no. 1-2, pp. 268-277, 2009.

[34] G. Moussavi and M. Mahmoudi, "Degradation and biodegradability improvement of the reactive red 198 azo dye using catalytic ozonation with $\mathrm{MgO}$ nanocrystals," Chemical Engineering Journal, vol. 152, no. 1, pp. 1-7, 2009.

[35] J. Crittenden and H. Montgomery Watson, Water Treatment: Principles and Design, John Wiley \& Sons, Hoboken, NJ, USA, 2005.

[36] S. Tong, R. Shi, H. Zhang, and C. Ma, "Catalytic performance of $\mathrm{Fe}_{3} \mathrm{O}_{4}-\mathrm{CoO} / \mathrm{Al}_{2} \mathrm{O}_{3}$ catalyst in ozonation of 2-(2,4dichlorophenoxy)propionic acid, nitrobenzene and oxalic acid in water," Journal of Environmental Sciences, vol. 22, no. 10, pp. 1623-1628, 2010.

[37] A. G. Gonçalves, J. J. M. Órfão, and M. F. R. Pereira, "Ceria dispersed on carbon materials for the catalytic ozonation of sulfamethoxazole," Journal of Environmental Chemical Engineering, vol. 1, no. 3, pp. 260-269, 2013.

[38] P. C. C. Faria, J. J. M. Órfão, and M. F. R. Pereira, "Activated carbon catalytic ozonation of oxamic and oxalic acids," Applied Catalysis B: Environmental, vol. 79, no. 3, pp. 237-243, 2008.

[39] H. Valdés and C. A. Zaror, "Heterogeneous and homogeneous catalytic ozonation of benzothiazole promoted by activated carbon: kinetic approach," Chemosphere, vol. 65, no. 7, pp. 11311136, 2006.

[40] L. Lei, L. Gu, X. Zhang, and Y. Su, "Catalytic oxidation of highly concentrated real industrial wastewater by integrated ozone and activated carbon," Applied Catalysis A: General, vol. 327, no. 2, pp. 287-294, 2007.

[41] P. M. Alvárez, J. F. García-Araya, F. J. Beltrán, I. Giráldez, J. Jaramillo, and V. Gómez-Serrano, "The influence of various factors on aqueous ozone decomposition by granular activated carbons and the development of a mechanistic approach," Carbon, vol. 44, no. 14, pp. 3102-3112, 2006.

[42] M. Sánchez-Polo, R. Leyva-Ramos, and J. Rivera-Utrilla, "Kinetics of 1,3,6-naphthalenetrisulphonic acid ozonation in presence of activated carbon," Carbon, vol. 43, no. 5, pp. $962-$ 969, 2005.

[43] M. E. Suárez-Ojeda, J. Carrera, I. S. Metcalfe, and J. Font, "Wet air oxidation (WAO) as a precursor to biological treatment of 
substituted phenols: refractory nature of the WAO intermediates," Chemical Engineering Journal, vol. 144, no. 2, pp. 205-212, 2008.

[44] R. C. Martins and R. M. Quinta-Ferreira, "Phenolic wastewaters depuration and biodegradability enhancement by ozone over active catalysts," Desalination, vol. 270, no. 1-3, pp. 90-97, 2011.

[45] R. Maciel, G. L. Sant'Anna Jr., and M. Dezotti, "Phenol removal from high salinity effluents using Fenton's reagent and photoFenton reactions," Chemosphere, vol. 57, no. 7, pp. 711-719, 2004.

[46] G. Busca, S. Berardinelli, C. Resini, and L. Arrighi, “Technologies for the removal of phenol from fluid streams: a short review of recent developments," Journal of Hazardous Materials, vol. 160, no. 2-3, pp. 265-288, 2008.

[47] A. Rubalcaba, M. E. Suárez-Ojeda, J. Carrera et al., "Biodegradability enhancement of phenolic compounds by hydrogen peroxide promoted catalytic wet air oxidation," Catalysis Today, vol. 124, no. 3-4, pp. 191-197, 2007.

[48] T. Olmez-Hanci and I. Arslan-Alaton, "Comparison of sulfate and hydroxyl radical based advanced oxidation of phenol," Chemical Engineering Journal, vol. 224, pp. 10-16, 2013.

[49] L. F. Liotta, M. Gruttadauria, G. di Carlo, G. Perrini, and V. Librando, "Heterogeneous catalytic degradation of phenolic substrates: catalysts activity," Journal of Hazardous Materials, vol. 162, no. 2-3, pp. 588-606, 2009.

[50] A. Santos, P. Yustos, T. Cordero, S. Gomis, S. Rodríguez, and F. García-Ochoa, "Catalytic wet oxidation of phenol on active carbon: stability, phenol conversion and mineralization," Catalysis Today, vol. 102-103, pp. 213-218, 2005. 

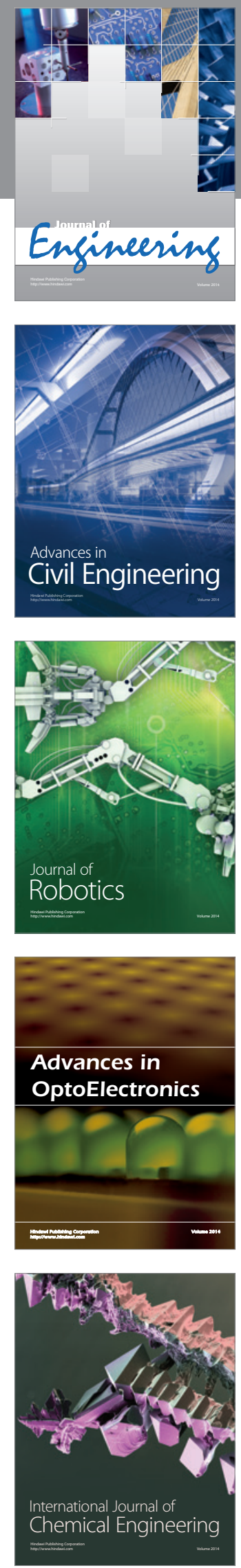

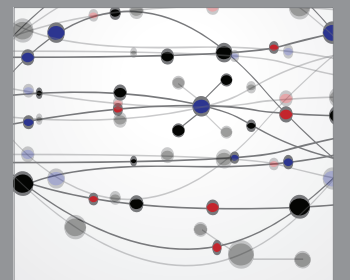

The Scientific World Journal
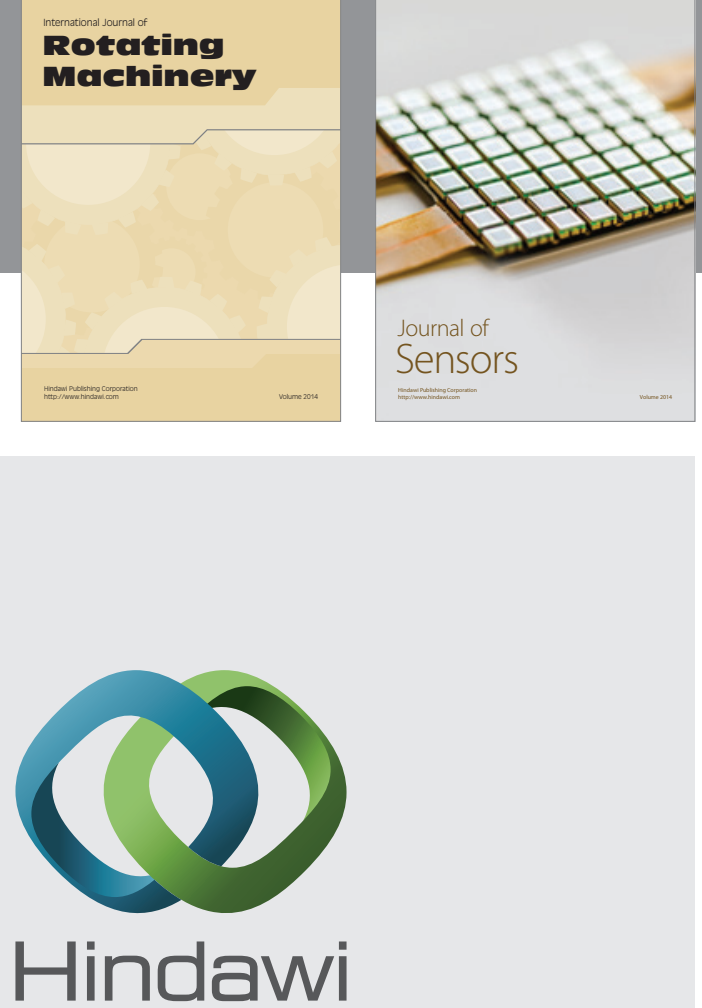

Submit your manuscripts at http://www.hindawi.com
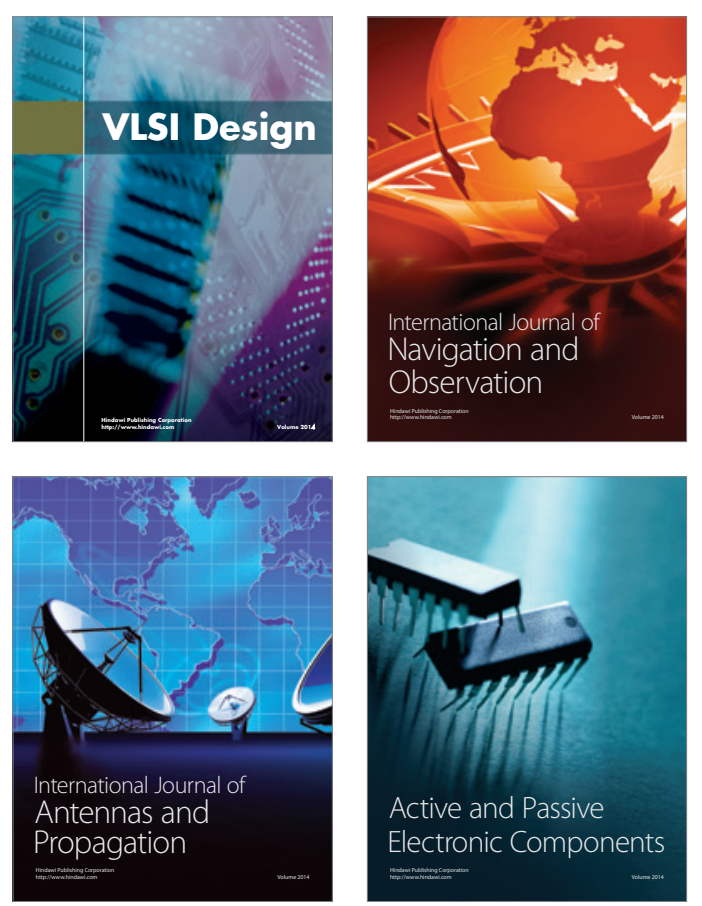
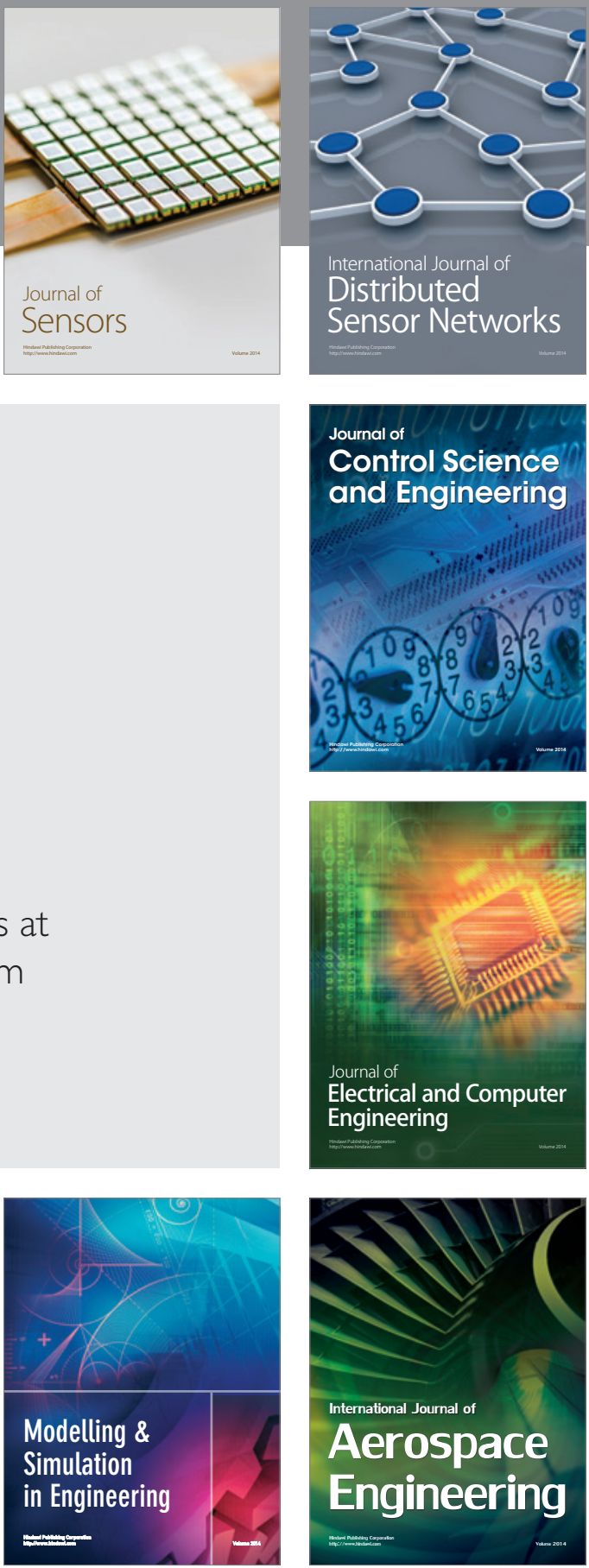

Journal of

Control Science

and Engineering
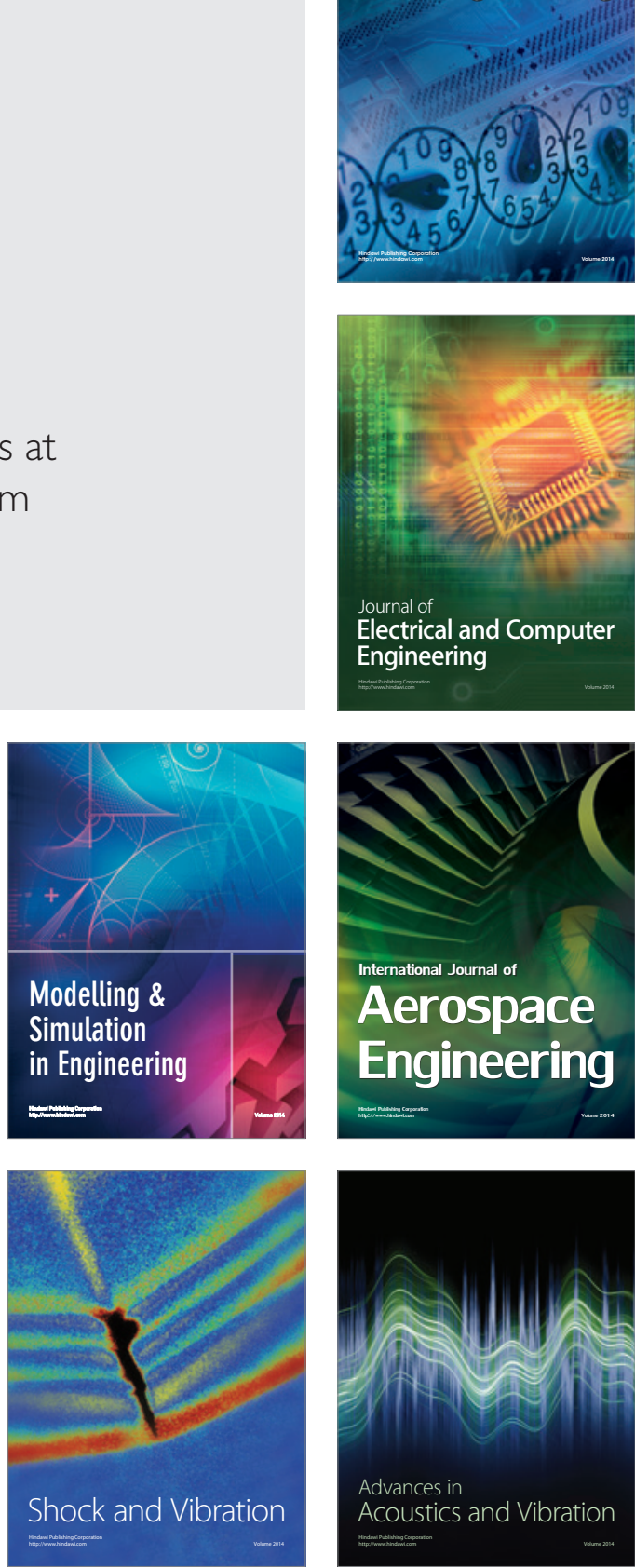